BBA 5 IO 70

\title{
Incorporation of long-chain and polyunsaturated acids into phosphati- date and phophatidylcholine
}

Glycerol is incorporated into the glycerolipids of many tissues by the pathway described by KENNEDY and his co-workers ${ }^{1,2}$. These reactions (Reactions ${ }^{-}-5$ ) provide diacylglycerols that may then form either trialcylglycerols or phosphatidyl derivatives.

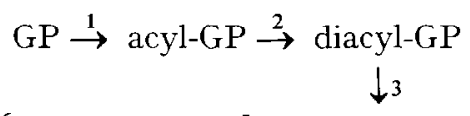

acyl-GPC $\underset{6}{\rightleftarrows}$ diacyl-GPC $\stackrel{5}{\leftarrow}$ diacylglycerol $\stackrel{4}{\rightarrow}$ triacylglycerol

One phenomenon not fully explained at the present is that mammalian tissue phospholipids contain a much higher content of long-chain polyunsaturated acids at the 2-position than do the triacylglycerols ${ }^{3,4}$. In fact, MATTSON AND VOLPENHEIN ${ }^{5}$ found in plant seed oils that acids with a chain length of more than $\mathrm{I} 8$ carbon atoms, regardless of their ethylenic bond content, were esterified almost exclusively at the primary position(s). One explanation would be that Reaction 4 selects only those diacylglycerols that do not contain polyunsaturated acids in accord with an earlier suggestion ${ }^{2}$. Alternatively, Reactions I and 2 may not effectively use these acids and thus produce diacylglycerols containing predominantly palmitate, oleate and linoleate. Polyunsaturated acids could then enter phosphatides via acyltransferasecatalyzed reactions (Reaction 6) with the monoacyl derivatives, ${ }^{6}$. The following experiments were designed to test the selectivity of the transfer of these acids in Reaction 2 in comparison to that for Reaction 6.

I-Acyl-GP was prepared by phosphorylation of monooleoylglycerol with $\mathrm{POCl}_{3}$ in chloroform ${ }^{8}$ and was isolated as the ethanol-insoluble sodium salt (phosphorus: ester $=\mathrm{I} .2$ ). Acyl-CoA derivatives were prepared by condensation of the acid chloride with CoA as described by REITz et al. ${ }^{\circ}$. Acid chlorides were obtained commercially or by treating the free acids (Hormel Institute) with oxalyl chloride. Quantitative gas chromatography of the methyl esters prepared from acyl-CoA's indicated purities of greater than $95 \%$ for the $20: 3,20: 4,20: 5$ and $22: I$ and greater than $90 \%$ for the 22:6 thiol esters. All other CoA thiol esters were more than $99 \%$ pure. T-Aryl-GPC, was prepared by treatment of egg phosphatidylcholine with phospholipase A (ref. Io) and was isolated by column chromatography on silicic acid, Rat and guinea-pig liver microsomes were prepared as described earlier ${ }^{6}$ and stored at $-I 5^{\circ}$ in $0.25 \mathrm{M}$ sucrose-I mM EDTA (25-40 $\mathrm{mg}$ protein $/ \mathrm{ml}$ ). Rat liver microsomes were treated with o.I vol. Io $\mathrm{mM}$ DFP in propylene glycol for $30 \mathrm{~min}$ at room temperature prior to the assay for acyltransferase activity. Acyl-transfer reactions were assayed by tollowing the increase in absorbance at $4 \mathrm{I} 2 \mathrm{~m} \mu$ produced by the reaction of the released mer-

Abbreviations: GP, L-glycerol-3-phosphate; GPC, L-glycerol-3-phosphorylcholine; DTNB, 5, $5^{\prime}-$ dithiobis(2-nitrobenzoic acid). 
TABLE I

EFFECT OF ACYL-COA, ACXL-GP AND PROTEIN CONCENTRATIONS ON I-ACYL-GP: ACYL-COA ACYLTRANSFERASE RATES

The reaction mixture contains $\mathrm{I} \mu$ mole $\mathrm{DTNB}, 90 \mu$ moles Tris-chloride $(\mathrm{pH} 7.4), 0.20 \mathrm{mg}$ protein (or as indicated) and $19 \mathrm{~m} \mu$ moles acyl-CoA (or as indicated) and $56 \mathrm{~m} \mu \mathrm{moles}$ acyl-GP (or as indicated) in a total volume of $\mathrm{I} . \mathrm{o} \mathrm{ml}$. The acyl-transfer rates are expressed in $\mathrm{m} \mu \mathrm{moles} / \mathrm{min}$ per $\mathrm{mg}$.

\begin{tabular}{|c|c|c|c|c|c|c|c|c|}
\hline \multirow{3}{*}{ Addition } & \multicolumn{8}{|c|}{$A C y l-C o A$} \\
\hline & \multicolumn{2}{|c|}{$16: 0$} & \multicolumn{2}{|l|}{$I 8: I$} & \multicolumn{2}{|c|}{$20: 2$} & \multicolumn{2}{|c|}{$20: 5$} \\
\hline & Rat & Guineapig & $R a \bar{t}$ & Gunea pig & Rat & Guinea pig & Rat & Guineapig \\
\hline \multicolumn{9}{|c|}{ Acyl-CoA (mumoles) } \\
\hline $\mathrm{I}_{4}$ & 28 & 22 & $2 \mathrm{I}$ & 21 & 9 & - & 10 & 5 \\
\hline I9 & 27 & 25 & 26 & 26 & 9 & - & I I & 6 \\
\hline 30 & 22 & 16 & $2 \mathrm{I}$ & 22 & 8 & $\cdots$ & 10 & 6 \\
\hline 50 & 20 & 15 & 23 & 15 & 6 & - & IO & 4 \\
\hline 75 & 16 & 20 & I 8 & 19 & 7 & - & 9 & 5 \\
\hline 100 & 4 & 12 & 13 & 17 & 5 & - & 8 & 6 \\
\hline \multicolumn{9}{|c|}{ Acyl-GP (mimoles) } \\
\hline 28 & 17 & - & 17 & - & & & & \\
\hline 35 & - & 33 & $\therefore$ & 19 & & & & \\
\hline 49 & 28 & 39 & 30 & - & & & & \\
\hline 63 & - & 38 & 27 & 47 & & & & \\
\hline $9^{r}$ & 25 & $3^{8}$ & 29 & 45 & & & & \\
\hline 105 & 23 & 36 & 23 & 50 & & & & \\
\hline 135 & - & 28 & 20 & 30 & & & & \\
\hline \multicolumn{9}{|c|}{ Protein (mg) } \\
\hline 0.10 & 24 & 32 & 37 & 48 & & & $x \mathrm{I}$ & 9 \\
\hline 0.20 & 30 & 29 & 34 & 45 & & & I3 & 7 \\
\hline 0.30 & 29 & 30 & 36 & 35 & & & I I & 7 \\
\hline $0.4^{\circ}$ & $2 \mathrm{I}$ & 20 & 25 & $3 r$ & & & 9 & 6 \\
\hline
\end{tabular}

captan with DTNB ${ }^{11}$. The reaction was initiated by adding acyl-CoA after a 2 -min preincubation of the protein. Control incubations were conducted for each acyl-CoA in the absence of acyl-GP and the observed endogenous rate (never greater than 5 $\mathrm{m} \mu \mathrm{moles} / \mathrm{min}$ per $\mathrm{mg}$ ) was subtracted from the rate observed in the presence of acylGP. I-Acyl-GPC: acyl-CoA acyltransferase was measured in the same manner except $30 \mathrm{~m} \mu$ moles of acyl-CoA and $\mathrm{I} 75 \mathrm{~m} \mu$ moles of $\mathrm{I}$-acyl-GPC were used.

To insure that the rates observed with different acyl-CoA's were optimal, the effect of varying amounts of acyl-CoA, acyl-GP and protein was determined. These results are summarized in Table I. Various concentrations of 4 different thiol esters were tested and found to give optimal rates uver a wide range of concentrations. In agreement with our earlier results ${ }^{6}$, high concentrations $(75-\mathrm{I} 00 \mu \mathrm{M})$ yielded lower rates of esterification with acyl-GP although the effect varied with different acyl-CoA's. Acyl-GP was rate limiting at lower concentrations and caused some inhibition at high concentrations. With low levels of acyl-CoA (I9 $\mu \mathrm{M})$ and acyl-GP $(55 \mu \mathrm{M})$ the assay gave a linear response to protein in the range of 0.10 to $0.30 \mathrm{mg}$ of protein (Table I). Particular attention was given to the above variables since earlier work ${ }^{6}$ indicated that a non-linear relationship can occur with some thiol esters. This effect may explain the different values for rat liver ${ }^{6}$. Some variation was observed in the absolute turnover numbers for different batches of the particulate enzyme preparation in this work, but the standard errors presented in Table II are sufficiently small to allow uscful comparisons among the various acid derivatives.

Acyl transferase rates for a series of acyl-CoA's with I-acyl-GP and r-acyl-GPC 
are given in Table II. In accord with earlier findings ${ }^{6}$, guinea-pig microsomes yielded slightly lower rates of esterification to I-acyl-GPC when compared to rat liver. With the exception of $I 8: 0$, the acyl-CoA's containing $I 6$ or $I 8$ carbon atoms were readily esterified to the 2-position of acyl-GP regardless of their degree of unsaturation whereas acyl-CoA's containing 20 or 22 carbon atoms were not. The polyunsaturated acyl-CoA's were, however, relatively better substrates in both transfers to the 2-position than their corresponding saturate or monoene analogs. Furthermore, the longchain polyunsaturated acyl-CoA's containing 20 carbon atoms were more rapidly esterified by rat liver microsomes to I-acyl-GPC than to acyl-GP.

TABLE II

RELATIVE RATES OF ACYL TRANSFER TO ACYL-GP AND ACYL-GPC

The reaction mixture contained I $\mu$ mole of DTNB, go $\mu$ moles of Tris-chloride ( $\mathrm{pH} 7.4$ ), 0.20 mg of protein and either ig mumoles acyl-CoA plus 56 mumoles I-acyl-GP or $25 \mathrm{~m} \mu \mathrm{moles}$ of acyl-CoA plus $175 \mathrm{~m} \mu$ moles 1 -acyl-GPC in a total volume of $\mathrm{I} .0 \mathrm{ml}$. The values presented (m $\mu \mathrm{moles} / \mathrm{min}$ per $\mathrm{mg}$ microsomal protein) are the averages of assays (number in parentheses) with at least 3 different preparations of the particulate fraction. Each assay involved a continual recording of the products formed and thus each rate represents a large number of recorded observations.

\begin{tabular}{|c|c|c|c|c|}
\hline \multirow[t]{2}{*}{ Acyl-Co.A } & \multicolumn{2}{|c|}{ Guinea-pig microsomes } & \multicolumn{2}{|c|}{ Rat-liver microsomes } \\
\hline & $I-a c y l-G P$ & $I-a c y l-G P C$ & $I-a c y l-G P$ & $I-a c y l-G P C$ \\
\hline $16: 0$ & $16.6 \pm 0.9(5)$ & $2.3 \pm 0.5(4)$ & $\mathrm{I} 8 . \mathrm{I} \ldots \mathrm{I} .6(4)$ & $5.7=1.7(4)$ \\
\hline I $8: 0$ & $9.1=0.8(6)$ & $2.0 \pm 0.5(4)$ & $9.9=1.6(4)$ & $1.7($ ref. 7$)$ \\
\hline I $8:$ I $(n-9)$ & $20.7 \div 1.4(7)$ & $12.4 \pm 0.3(4)$ & $22.7 \pm 1.9(6)$ & 12.4 (ref. 7 ) \\
\hline I $8: 2(n-6)$ & $2 \mathrm{I} .5=0.7(5)$ & $14.4=0.5(4)$ & I 8.I I $1.5(5)$ & $21.5 \pm 0.7(4)$ \\
\hline I $8: 3(n-3)$ & $18.3=0.5(5)$ & II.9 $11.3(4)$ & 19.6 上 $1.5(4)$ & 14.6 (ref. 7 ) \\
\hline $20: 0$ & $0.6 \pm 0.2(6)$ & $0.3 \pm 0.3(4)$ & 0.4 . $0.1(4)$ & \\
\hline $20: 1(n-9)$ & $0.8+0.3(6)$ & $1.6=0.1(4)$ & $3.9+0.4(4)$ & $\mathrm{I} .5+0.6$ \\
\hline $20: 2(n-9)$ & $4.2=0.4(6)$ & $9.0=0.9(4)$ & $3.9=0.5(4)$ & $16.8=I .9(4)$ \\
\hline $20: 3(n-6)$ & $6.2 \pm 0.8(6)$ & $19.5=0.5(4)$ & $7 \cdot 3=0.6(5)$ & $29.2 \dashv-0.4(2)$ \\
\hline $20: 4(n-6)$ & $5 \cdot 4=0.8(4)$ & $10.6\rfloor 0.9(4)$ & $7.6 \pm 0.8(4)$ & $22.3=I .5(4)$ \\
\hline $20: 5(n-3)$ & $5.7 \pm 0.9(5)$ & $15.0-0.3(4)$ & $6.8 \pm 1.0(3)$ & $29.3 \pm$ I.4 (4) \\
\hline $22: I(\mathrm{n}-9)$ & $1.6 \pm 0.5(5)$ & $0.2=0.1(4)$ & $0.8 \div 0.2(3)$ & $0.0(4)$ \\
\hline $22: 6(n-3)$ & $4.2 \pm 0.2(5)$ & $5.8=0.7(4)$ & $4.2 . 上 0.3(3)$ & $7.3 \leftarrow 1.3(4)$ \\
\hline
\end{tabular}

Although the degree of unsaturation of the acyl group of the CoA thiol ester did influence the rate, it appeared to be of somewhat less importance to the acyl-GP: acyl-CoA acyltransferase than the length of the carbon chain. This contrasts to the conclusion of STOFFel, De Tomas AND Schiefer" "Der Einbau der Fettsäuren war unabhängig von Struktur, Kettenlänge und Zahl der Doppelbindungen”. Although our data do not preclude the synthesis of an arachidonoyl-diacylglycerol, they indicate that its rate of synthesis might be small compared to that for oleoyl- and linoleoyldiacylglycerols. Such a suggestion is in keeping with the observed low content of $20: 4$ at the 2-position of rat liver triacylglycerols. Comparison of the relative rates of esterification of $20: 2,20: 3,20: 4,20: 5$ to I-acyl-GP and I-acyl-GPC by rat liver particles indicates that a more efficient incorporation of these polyunsaturated fatty acids may occur by the combined actions of phospholipases and acyltransferases upon phosphatidylcholine molecules rather than by way of phosphatidate synthesis de novo.

This work was supported in part by a grant (AM 053I0) from the United States Public Health Service. Mr. Mustafa EL-ShIEkH provided technical assistance.

The University of Michigan, Department of Biological

EdWARd E. HiLl Chemistry, Ann Arbor, Mich. 48ro4 (U.S.A.) William E. M. Lands 
I E. P. Kennedy, Federation Proc., 20 (I96I) 934.

2 S. B. Weiss, E. P. Kennedy and J. Y. Kiyasu, J. Biol. Chem., 235 (ig6o) 40.

3 S. P. M. Slakey and W. E. M. Lands, Lipids, 3 (1968) 30.

4 H. Brockerhoff, Comp. Biochem. Physiol., I9 (I966) I.

5 F. H. Mattson and R. A. Volpenhein, J. Biol. Chem., 236 (I96I) I89I.

6 W. E. M. Lands and P. Hart, J. Biol. Chem., 240 (I965) 1950.

7 W. E. M. Lands, M. Blank, L. J. Nutter and U. Privett, Lipids, I (1966) 224.

8 E. BAER AND A. KINDLER, Biochemistry, I (I962) 5 I 8.

9 R. C. Reitz, W. E. M. Lands, W. W. Christie and R. T. Holman, J. Biol. Chem., 243 (ig68) in the press.

io W. E. M. Lands, $J$. Am. Oil Chemists' Soc., 42 (1965) 465.

i I G. L. Ellman, Arch. Biochem. Biophys., 82 (I959) 70.

I 2 W. Stoffel, M. E. De Tomas and H. B. Schiefer, Z. Physiol. Chem., 348 (1967) 882.

Received March 4th, 1968

Biochim. Biophys. Acta, I 52 (1968) 645-648

BBA 51069

\section{Biosynthesis of cortisol from $3 \beta, 17 \alpha, 21$-trihydroxypregn-5-en-20-one by the intact human foetus at midpregnancy}

It has been suggested previously that $3 \beta, I 7 \alpha, 2$ I-trihydroxypregn-5-en-20-one $\left(\mathbf{I} 7 \alpha, 2 \mathbf{I}-\Delta^{5}-\mathrm{P}\right)$ is a normal constituent of human cord blood at term ${ }^{1}$. To explore the fate of this compound in the foetal compartment, we have perfused 2 foetuses at midpregnancy with $5^{\circ}$ and $70 \mu \mathrm{C}$, respectively, of $\left[7 \alpha^{-3} \mathrm{H}\right] \mathrm{I} 7 \alpha, 2 \mathrm{I}-\Delta^{5}-\mathrm{P}^{*}$.

The preparation and purification of this compound ${ }^{2}$ and the conditions of perfusion $^{3}$ have been described elsewhere. The radiochemical purity of the material perfused is indicated in Table $\mathrm{I}$.

\section{TABLE I}

RADIOCHEMICAL PURITY OF THE PERFUSED $\left[7 \alpha^{3}{ }^{3} \mathrm{H}\right]-3 \beta, \mathrm{I} 7 \alpha, 2$ I-TRIHYDROXYPREGN-5-EN-2O-ONE $0.04 \mu \mathrm{C}$ of $\left[7 \alpha^{-3} \mathrm{H}\right]-\mathrm{I} 7 \alpha, 2 \mathrm{I}-1^{5}-\mathrm{P}$ were mixed with $25 \mathrm{mg}$ of authentic $3 \beta, \mathrm{I} 7 \alpha, 2 \mathrm{I}$-trihydroxypregn5-en-2o-one.

\begin{tabular}{lll}
\hline Solvent & $\begin{array}{l}\text { Crystals } \\
\text { (disint./min per mg) }\end{array}$ & $\begin{array}{l}\text { Mother liquors } \\
\text { (disint./min per mg) }\end{array}$ \\
\hline Methanol & 3430 & 3630 \\
Ethanol-benzene & 3410 & 3470 \\
\hline
\end{tabular}

The foetuses were perfused for 30 min. Upon completion of the perfusion, the adrenals were removed, homogenized and extracted by a method described previously 4 . The unconjugated radioactive material (corresponding in both cases to $\mathrm{I} \%$ of the perfused dose) was subjected to paper partition chromatography in System $\mathrm{I}^{* *}$,

Abbreviations and trivial names: DHA : $3 \beta$-hydroxyandrost-5-en-I 7 -one; $\lambda^{5}$-P: $3 \beta$-hydroxypregn5-en-2o-one; I $7 \alpha, \lambda^{\circ}-\mathrm{P}: 3 \beta$, I $7 \alpha$-dihydroxypregn-5-en-2o-one; I $7 \alpha, 2 \mathrm{I}-\lambda^{5}-\mathrm{P}: 3 \beta, \mathrm{I} 7 \alpha, 2 \mathrm{I}$-trihydroxypregn-5-en-20-one; cortisol: I I $\beta$, I $7 \alpha, 2$ I-trihydroxypregn-4-ene-3, 20-dione.

* Purchased from New England Nuclear Co., Boston, Mass. (Li.S.A.) in the form of the 3,2Idiacetate (specific activity: $3.0 \mu \mathrm{C} / \mu \mathrm{g}$ ).

** Systems used for paper partition chromatography at room temperature: No. I. chloroform/ formamide; No. 2. isooctane-tevt.-butanol-water (10:9:5, by vol.); No. 3. ethyl acetate-toluene- 